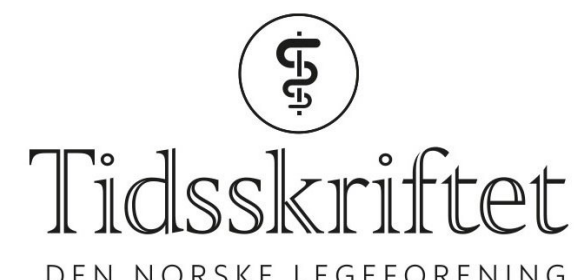

DEN NORSKE LEGEFORENING

\title{
Norges mikrobiologiske utbruddsberedskap er truet
}

\author{
DEBATT

\section{ELLING ULVESTAD} \\ E-post: elling.ulvestad@helse-bergen.no \\ Elling Ulvestad er dr.med., avdelingssjef ved Mikrobiologisk avdeling, Haukeland \\ universitetssjukehus og professor ved Universitetet i Bergen. \\ Forfatteren har fylt ut ICMJE-skjemaet og oppgir ingen interessekonflikter.
}

\section{$\varnothing Y$ VIND KOMMEDAL}

Øyvind Kommedal er ph.d., seksjonsoverlege ved Mikrobiologisk avdeling, Haukeland universitetssjukehus og førsteamanuensis, Universitetet i Bergen. Forfatteren har fylt ut ICMJE-skjemaet og oppgir ingen interessekonflikter.

\section{GUNNAR SKOV SIMONSEN}

Gunnar Skov Simonsen er dr.med. professor og avdelingsleder ved Avdeling for mikrobiologi og smittevern, Universitetssykehuset Nord-Norge.

Forfatteren har fylt ut ICMJE-skjemaet og oppgir ingen interessekonflikter.

\section{FREDRIK MÜLLER}

Fredrik Müller er dr. med., professor og avdelingsleder ved Avdeling for mikrobiologi, Oslo universitetssykehus.

Forfatteren har fylt ut ICMJE-skjemaet og oppgir ingen interessekonflikter.

\section{TRULS MICHAEL LEEGAARD}

Truls Michael Leegaard er dr.med., førsteamanuensis og avdelingsoverlege ved Avdeling for mikrobiologi og smittevern, Akershus universitetssykehus.

Forfatteren har fylt ut ICMJE-skjemaet og oppgir ingen interessekonflikter.

\section{IREN HØYLAND LÖHR}

Iren Høyland Löhr er ph.d. og avdelingsoverlege ved Avdeling for medisinsk mikrobiologi, Stavanger universitetssjukehus.

Forfatteren har fylt ut ICMJE-skjemaet og oppgir ingen interessekonflikter.

\section{SVEIN ARNE NORDBØ}

Svein Arne Nordbø er førsteamanuensis og overlege ved Avdeling for medisinsk mikrobiologi, St. Olavs hospital.

Forfatteren har fylt ut ICMJE-skjemaet og oppgir ingen interessekonflikter.

Covid-19-pandemien har vist at mikrobiologiske laboratorier må møte smitteutbrudd med bred diagnostisk kompetanse, høy testkapasitet og effektiv infrastruktur. En ny EUforordning truer nå utbruddsberedskapen. 
Covid-19 ble navnet på luftveissykdommen som i desember 2019 spredte seg pandemisk fra byen Wuhan i Kina. I arbeidet med identifisering av det sykdomsframkallende viruset ble det allerede 17. januar publisert primere og prober som kunne anvendes til polymerasekjedereaksjon (PCR)-diagnostikk (1). Dermed kunne laboratorier med erfaring i å utvikle egne PCR-tester bestille skreddersydde reagenser og selv etablere testen. Allerede i månedsskiftet januar/februar var mikrobiologiske laboratorier i Norge klare til å teste for sars-CoV-2 (2).

Initialt var det få smittede i Norge, og med strenge retningslinjer for hvem som skulle testes ble kapasiteten i de mikrobiologiske laboratoriene knapt satt på prøve. Men utover i mars, med stadig flere smittede, ble det nødvendig for mange laboratorier å skalere ned og til dels legge til side annen diagnostikk for å gjøre plass til mer koronadiagnostikk. Den samlede kapasiteten i Norge var på denne tiden rundt zo ooo koronatester per uke, og strenge testkriterier forble nødvendige for å opprettholde likevekten mellom tilbud og etterspørsel.

\section{Test- og kapasitetsutvikling}

Uten vaksine eller annen effektiv behandling er vårt eneste forsvar mot pandemiske agens å stoppe smitten. Siden effektive karantene- og isolasjonstiltak forutsetter kunnskap om hvem som er smittet, har Verdens helseorganisasjon ved gjentatte anledninger framhevet betydningen av høy testaktivitet. I samsvar med dette ga Helsedirektoratet 3. april de største mikrobiologiske laboratoriene et hasteoppdrag der det ble uttrykt behov for å øke testkapasiteten til 300 ooo tester per uke.

På dette tidspunktet var det allerede internasjonal knapphet på prøvetakingsutstyr, reagenser for rensing av RNA, enzymer for PCR-reaksjoner, plastartikler og analyseinstrumenter. Det var i tillegg iverksatt streng nasjonal rasjonering og prioritering av de mest kritiske artiklene. Likevel lot det seg gjøre å skalere opp testkapasiteten i laboratoriene, bl.a. ved lån og innkjøp av medisinskteknisk utstyr, innleie av bioingeniører, $\emptyset \mathrm{kt}$ arealutnyttelse og-ikke minst - ved nasjonal produksjon av reagenser for RNA-rensing gjennom en metode utviklet av NTNU. Betydningen av å ha instrumenter som tillot fleksibel bruk av reagenser, ble dermed aksentuert.

\section{Nasjonal beredskapsplan}

I desember 2019 ble Nasjonal beredskapsplan mot utbrudd av alvorlige smittsomme sykdommer ferdigstilt (3). I planen gis betraktninger rundt medisinsk mikrobiologisk diagnostikk og beredskap. Det står mye om krav til referansefunksjoner og rollen Nasjonalt beredskapslaboratorium er tenkt å fylle, men forbausende lite om de regionale mikrobiologiske laboratorienes funksjoner.

Som vist under covid-19-pandemien er det uklokt kun å satse på kommersielle tester i en utbruddssituasjon

Covid-19-pandemien har gjort det tydelig at de regionale laboratoriene er bærebjelken i diagnostisk mikrobiologisk beredskap, og Nasjonal beredskapsplan må følgelig omformuleres og utvides med sikte på å klargjøre deres funksjon. I tillegg må planen drøfte forsyningstjenestens betydning for ivaretakelse av tilstrekkelig testkapasitet, og den bør omhandle en nasjonal strategi for produksjon av kritiske artikler. Den pågående pandemien viste at verdensmarkedet relativt raskt gikk tom for prøvetakingsutstyr og laboratorieforbruksmateriell, og videre - at mange internasjonale produsenter fikk pålegg fra egne myndigheter om å prioritere hjemmemarkedet.

\section{En tapt mulighet?}

Gjennom covid-19-pandemien har laboratoriene dokumentert at de raskt kan utvikle diagnostikk også for tidligere ukjente smittestoff. Selv om det per i dag ikke finnes en 
sentral godkjenningsordning for etablering av ny diagnostikk, er de fleste laboratoriene akkrediterte og har dermed en formell godkjenning av egen valideringskompetanse. Kvalitetsmessig står ikke egenutviklede PCR-tester tilbake for kommersielle tester, og vi bruker de samme metodene for å evaluere egne så vel som kommersielle tester.

Som vist under covid-19-pandemien er det uklokt kun å satse på kommersielle tester i en utbruddssituasjon. Selv med forsert godkjenning fra myndighetene tar det flere måneder før slike tester når markedet, og når de først er gjort tilgjengelige, vil de være et knapphetsgode over lang tid.

Etter vår fortolkning av forordningen vil vi heller ikke kunne investere i fleksible instrumenter egnet for egentilvirkede tester eller å opprettholde store lagre med testingredienser

Etablering av ny diagnostikk utføres rutinemessig ved alle de mikrobiologiske laboratoriene i Norge. Det er bekymringsfullt at denne praksisen - og beredskapen som ligger innbakt i den - nå trues av en ny EU-forordning. Den såkalte IVD-forordningen (2017/746) har som formål å sikre kvalitet innenfor diagnostisk virksomhet (4), men legger samtidig betydelige begrensninger på bruk av egentilvirkede tester (5). Rett nok åpner forordningen for unntak (in house-unntaket), men disse unntakene er så pass begrensete at de får liten praktisk betydning. Vi kan heller ikke se at Helse- og omsorgsdepartementets vurdering av forordningen ivaretar det beredskapsmessige aspektet (6).

Norge har frist til mai 2022 med å implementere forordningen. En konsekvens av implementering vil være at ekspertisen vi har bygget opp for å etablere egenutviklede PCRtester, gradvis vil gå tapt. Etter vår fortolkning av forordningen vil vi heller ikke kunne investere i fleksible instrumenter egnet for egentilvirkede tester eller å opprettholde store lagre med testingredienser. Forordningen vil dermed gjøre de mikrobiologiske laboratoriene mindre beredt til å møte neste pandemi.

LITTERATUR:

1. Corman V, Bleicker T, Brünink S et al. Diagnostic detection of 2019-nCoV by real-time RT-PCR. https://www.who.int/docs/default-source/coronaviruse/protocol-v2-1.pdf Lest 15.5.2020.

2. Haukeland er klar til å teste for Wuhan-viruset. Bergens Tidende 28.1.2020.

https://www.bt.no/nyheter/lokalt/i/WbBdKg/haukeland-er-klar-til-aa-teste-for-wuhan-viruset Lest 26.5.2020.

3. Nasjonal beredskapsplan mot utbrudd av alvorlige smittsomme sykdommer. Oslo: Helse- og omsorgsdepartementet, 2019.

https://www.regjeringen.no/globalassets/departementene/hod/fellesdok/rapporterplaner/nasjonal_b eredskapsplan_smittevern.pdf Lest 15.5.2020.

4. Regulation (EU) 2017/746 of the European Parliament and of the Council of 5 April 2017 on in vitro diagnostic medical devices and repealing Directive 98/79/EC and Commission Decision 2010/227/EU. https://eur-lex.europa.eu/eli/reg/2017/746/oj Lest 15.5.2020.

5. Müller F, Leegaard TM, Simonsen GS et al. Ny EU-forordning truer pandemitester. Aftenposten 20.4.2020.

https://www.aftenposten.no/meninger/kronikk/i/e8LgRg/ny-eu-forordning-truer-pandemitester Lest 15.5.2020.

6. Prop. 46 LS (2019-2020).

https://www.regjeringen.no/no/dokumenter/prop.-46-ls-20192020/id2691742/?ch=1 Lest 27.5.2020.

Publisert: 29. juni 2020. Tidsskr Nor Legeforen. DOI: 10.4045/tidsskr.20.0451

Mottatt 19.5.2020, første revisjon innsendt 28.5.2020, godkjent 2.6.2020.

(C) Tidsskrift for Den norske legeforening 2020. Lastet ned fra tidsskriftet.no 